\title{
Influence of Foliar Fertilization of Micronutrients on Leaf Micro Nutrient Status of Mandarin Orange (Citrus reticulata Blanco.) in Lower Pulney Hills
}

\author{
C.J. Nithin Kumar ${ }^{1 *}$, J. Rajangam², K. Balakrishnan ${ }^{3}$ and Lokesh Bora ${ }^{4}$ \\ ${ }^{1}$ Department of Fruit Science, University of Horticultural Science, Bagalakot, \\ Karnataka -587104, India \\ ${ }^{2}$ Department of Fruit Crops, Horticultural College and Research Institute, \\ Periyakulam, TNAU, Tamil Nadu, India \\ ${ }^{3}$ Department of Crop physiology, Agricultural College and Research Institute - Madurai, \\ TNAU, Tamil Nadu, India \\ ${ }^{4}$ Department of Fruit Crops, Horticultural College and Research Institute, \\ Coimbatore, TNAU, Tamil Nadu, India \\ *Corresponding author
}

\section{A B S T R A C T}

\section{Keywords}

Mandarin orange, Micro-nutrients, Foliar application, Leaf nutrient status.

Article Info

Accepted: 04 April 2017 Available Online: 10 May 2017
Experiment on effect of foliar application of micronutrients ( $\mathrm{Zn}, \mathrm{Fe}, \mathrm{B}, \mathrm{Mn}$ and $\mathrm{Cu}$ ) on mandarin orange leaf micro nutrient status was carried out during 2015-16 at lower pulney hills of Tamilnadu, India. The results showed that foliar application of micronutrient alone significantly increased the individual micronutrient content and micronutrients in combination compare to control. Therefore application of micronutrients as foliar spray reduces incidence of deficiency calamities, in turn flourishes the growth and yield attributes subsequently.

\section{Introduction}

Fruits are nature's gift to mankind. These are not only delicious and refreshing but are also the chief source of vitamins and minerals. Among them Citrus (Citrus reticulata Blanco.) is one of the most important fruit crops of the globe, extensively cultivated in tropical and sub-tropical climate. In India, there are 26 states involved in citrus production but nine states cover more than $70 \%$ of area and $89 \%$ of total production. India is the fourth largest citrus producing country in the world contributing 6.5 percent of production. In India, citrus ranks $3^{\text {rd }}$ in area and production, area of citrus fruit was about 0.98 million hectares with a production of 11.06 million tons and average productivity of 9.69 tons/ha (Anon, 2016). Total mandarin production in India is 3.86 million tons with 0.35 million ha area and 9.3 tons/ha as productivity. Citrus requires 17 essential elements for the normal growth and production. Deficiency of' micronutrients 
occur at various stages of growth and developments of citrus plants. Micronutrients are required in very small quantities, yet they are very effective in regulating plant growth. Application of these mineral nutrients in deficiency condition improves the growth and development of citrus tree and also physicochemical composition of fruits. A number of studies on micronutrient deficiencies in citrus have been reported and detailed investigations were done on the effect of application of micronutrients especially zinc, iron, boron, manganese and copper on growth and development of citrus trees. Application of these nutrients through foliar spray have resulted perceptible changes in several aspects of growth, flowering, fruit set, yield and quality of citrus species (Babu and Yadav, 2005). Foliar application of nutrients often gives a quicker response than application to soil (Obreza et al., 2010; Anees et al., 2011), since plant nutrients are readily absorbed through the leaf surface. Swietlik (2002) reported that mineral nutrient enter into leaf in three steps: (1) penetration through the cuticle and epidermal walls; (2) adsorption on the surface of the plasmalemma and (3) passage through the plasmalemma into cytoplasm. Foliar treatments are also necessary in cases of immobilization processes which make application to the soils ineffective. Foliar absorption of nutrient is influenced by various factor, among which plant species, leaf age, nutrient type and concentration, product formulation, climatic conditions and the nutritional status of the plant (Swietlik and Faust, 1984).Growth of citrus also influenced by micronutrient such as Zinc ( $\mathrm{Zn})$, Iron $(\mathrm{Fe})$, Boron (B), Manganese (Mn) and Copper $(\mathrm{Cu})$ application. These elements effect metabolic functions in plant system. Zinc $(\mathrm{Zn})$ is an important micro element essential for plants due to its involvement in the synthesis of tryptophan which is a precursor of indole acetic acid synthesis (Ahmad et al., 2012). Zn is required for the activity of various enzymes, such as dehydrogenases, aldolases, isomerases, transphosphorylases, RNA and DNA polymerases (Swietlik, 1999). It has important role in starch metabolism, and acts as co-factor for many enzymes, affects photosynthesis reaction, nucleic acid metabolism and protein biosynthesis (Alloway, 2008). Bergmann (1992) reported that, zinc is believed to be involved in chlorophyll synthesis through its influence on protein, carbohydrate and energy metabolism. Taiz and Zeiger (1994) reported that, many enzymes require zinc ions $\left(\mathrm{Zn}^{2+}\right)$ for their activity, and zinc may be required for chlorophyll biosynthesis in some plants. Iron $(\mathrm{Fe})$ is one of the most important micronutrients for plant growth. It is involved in various physiological processes of plant systems, namely chlorophyll formation and degradation synthesis of protein which contains chloroplasts and electron carriers in enzyme systems (Somasundaram et al., 2011). In addition, $\mathrm{Fe}$ is part of protein ferredoxin and is required in nitrate and sulfate reduction. $\mathrm{Fe}$ is essential in maintenance of chlorophyll in plant and also plant metabolism (Photosynthesis and respiration). Boron (B) as a micronutrient plays significant role in growth, productivity of citrus and resistance to disease infection. It increases pollen grain germination, pollen tube elongation, consequently increasing fruit set percentage and seeds, fruit development and finally the yield (Abd-Allah, 2006). It is necessary in the synthesis of the base for RNA and in cellular activities and shown to promote root growth. B is important in the Translocation of sugar from leave is important to enhance photosynthesis Srivastava and Singh (2003). Manganese (Mn) plays a vital role in plant physiological processes (viz., photosynthesis, respiration, and nitrogen metabolism/assimilation). Manganese (Mn) primarily functions as part of the plant enzyme system, activating several metabolic functions (Somasundaram et al., 
2011). It is involved in the oxygen-evolving step of photosynthesis and membrane function, as well as serving as an important activator of numerious enzyme in the cell (Wiedenhoeft, 2006). Copper (Cu) is involved in stimulation of lignification of all plant cell walls, photosynthesis and electron carriers in enzyme systems of plant (Somasundaram et al., 2011). It plays an important role in the synthesis and or stability of chlorophyll land other plant pigments.

\section{Materials and Methods}

The field experiment was conducted in farmer field under lower Pulney hills of Kaanalkadu (Thadiyankudisai), Tamilnadu during the year 2014-16. For conducting this study six year old uniform trees of mandarin orange were selected. Soils of pulney hill region are red laterite having brown to dark brown colour. They are deep well drained and possess sandy clay loam structure which is appropriate for citrus cultivation. An altitude of $1098 \mathrm{~m}$ above MSL and the annual rainfall is around $1400 \mathrm{~mm}$. The mean maximum and minimum temperature were $32.6{ }^{\circ} \mathrm{C}$ and $17.7{ }^{\circ} \mathrm{C}$ respectively with mean relative humidity of $66.5 \%$.

There were 15 treatment replicated thrice tested in randomized block design. The effects of $\mathrm{ZnSO} 4(0.2 \%), \mathrm{FeSO}_{4}(0.2 \%)$, $\mathrm{H}_{3} \mathrm{BO}_{4}(0.2 \%), \mathrm{MnSO}_{4}(0.3 \%)$ and $\mathrm{CuSO}_{4}$ $(0.4 \%)$ alone or in combination was studied. The micronutrient were applied as a foliar sprays thrice at monthly interval from July to October 2015 and spray was given in the evening hours between 3.00-5.00 pm by using a hand sprayer. The required quantities of micronutrients were dissolved in water separately and then $\mathrm{pH}$ of these nutrient solutions was adjusted by lime and sprayed in vegetative, flowering and fruit set stages. The simple water spray was done on the tree under control treatment. In each spray treatment
Teepol was added as sticking agent in prepared solution. The four to five months old 30-50 leaf sample were collected for analysis. The leaf samples were analyzed for $\mathrm{Zn}, \mathrm{Fe}$, $\mathrm{Mn}$ and $\mathrm{Cu}$ by the following standard procedure lay out by Jackson (1973) and Humphries (1956). Observation of growth and estimation of leaf micro nutrient content were recorded and data were subjected to statistical analysis.

\section{Treatment details}

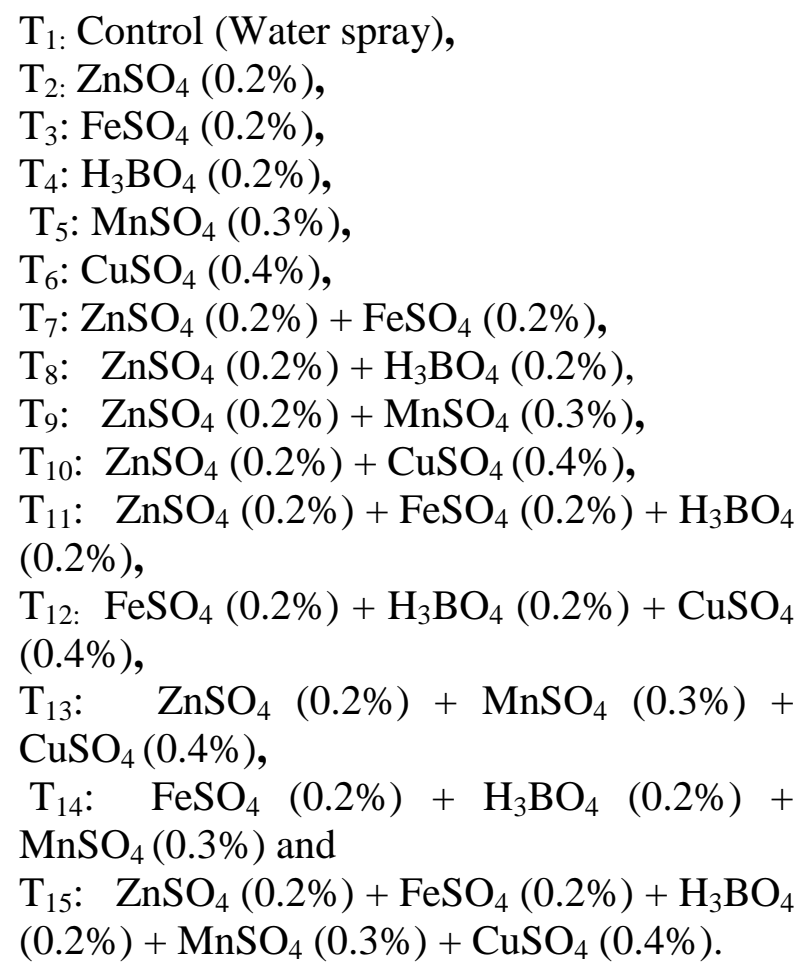

\section{Results and Discussion}

\section{Leaf Nutrient content}

Zinc is one of the important micronutrient for its role in enzyme activity in various crop plants. Zinc plays a key role in auxin and protein synthesis, cell membrane integrity and involved in ion transport. The data on leaf zinc varied significantly among the treatments at different stages (Table 1). 
Table.1 Effect of foliar application of micronutrients on leaf zinc content (ppm)

\begin{tabular}{|c|c|c|c|}
\hline Treatments & Vegetative stage & Flowering stage & Fruit set stage \\
\hline $\mathbf{T}_{\mathbf{1}}$ & 12.20 & 11.24 & 10.23 \\
\hline $\mathbf{T}_{\mathbf{2}}$ & 35.08 & 34.54 & 34.01 \\
\hline $\mathbf{T}_{\mathbf{3}}$ & 15.03 & 14.47 & 14.05 \\
\hline $\mathbf{T}_{\mathbf{4}}$ & 14.23 & 14.02 & 13.89 \\
\hline $\mathbf{T}_{\mathbf{5}}$ & 14.36 & 13.32 & 12.45 \\
\hline $\mathbf{T}_{\mathbf{6}}$ & 14.76 & 13.67 & 13.13 \\
\hline $\mathbf{T}_{\mathbf{7}}$ & 33.05 & 32.43 & 31.76 \\
\hline $\mathbf{T}_{\mathbf{8}}$ & 28.01 & 27.68 & 26.87 \\
\hline $\mathbf{T}_{\mathbf{9}}$ & 26.97 & 26.08 & 26.73 \\
\hline $\mathbf{T}_{\mathbf{1 0}}$ & 27.43 & 27.18 & 26.77 \\
\hline $\mathbf{T}_{\mathbf{1 1}}$ & 34.53 & 33.73 & 32.78 \\
\hline $\mathbf{T}_{\mathbf{1 2}}$ & 17.12 & 16.94 & 16.53 \\
\hline $\mathbf{T}_{\mathbf{1 3}}$ & 32.92 & 32.65 & 32.01 \\
\hline $\mathbf{T}_{\mathbf{1 4}}$ & 17.13 & 16.23 & 15.67 \\
\hline $\mathbf{T}_{\mathbf{1 5}}$ & 33.42 & 33.20 & 32.42 \\
\hline $\mathbf{S E d}_{\mathbf{C D}(\mathbf{0 . 0 5})}$ & 0.603 & 0.602 & 0.602 \\
\hline
\end{tabular}

Table.2 Effect of foliar application of micronutrients on leaf iron content (ppm)

\begin{tabular}{|c|c|c|c|}
\hline Treatments & Vegetative stage & Flowering stage & Fruit set stage \\
\hline $\mathbf{T}_{\mathbf{1}}$ & 103.2 & 102.3 & 100.8 \\
\hline $\mathbf{T}_{\mathbf{2}}$ & 108.2 & 106.2 & 105.2 \\
\hline $\mathbf{T}_{\mathbf{3}}$ & 162.1 & 159.2 & 158.2 \\
\hline $\mathbf{T}_{\mathbf{4}}$ & 107.8 & 105.4 & 104.3 \\
\hline $\mathbf{T}_{\mathbf{5}}$ & 106.2 & 105.2 & 103.2 \\
\hline $\mathbf{T}_{\mathbf{6}}$ & 106.8 & 105.2 & 104.5 \\
\hline $\mathbf{T}_{\mathbf{7}}$ & 150.2 & 148.3 & 145.3 \\
\hline $\mathbf{T}_{\mathbf{8}}$ & 118.3 & 116.6 & 114.3 \\
\hline $\mathbf{T}_{\mathbf{9}}$ & 111.3 & 110.4 & 109.8 \\
\hline $\mathbf{T}_{\mathbf{1 0}}$ & 119.2 & 116.5 & 113.5 \\
\hline $\mathbf{T}_{\mathbf{1 1}}$ & 160.1 & 157.2 & 154.4 \\
\hline $\mathbf{T}_{\mathbf{1 2}}$ & 155.7 & 154.8 & 153.5 \\
\hline $\mathbf{T}_{\mathbf{1 3}}$ & 119.5 & 115.2 & 114.3 \\
\hline $\mathbf{T}_{\mathbf{1 4}}$ & 155.1 & 154.6 & 152.6 \\
\hline $\mathbf{T}_{\mathbf{1 5}}$ & 156.3 & 154.1 & 153.2 \\
\hline $\mathbf{S E d}_{\mathbf{C D}(\mathbf{0 . 0 5})}$ & 3.584 & 1.572 & 1.561 \\
\hline
\end{tabular}


Table.3 Effect of foliar application of micronutrient on leaf manganese content (ppm)

\begin{tabular}{|c|c|c|c|}
\hline Treatments & Vegetative stage & Flowering stage & Fruit set stage \\
\hline $\mathbf{T}_{\mathbf{1}}$ & 30.34 & 30.25 & 30.16 \\
\hline $\mathbf{T}_{\mathbf{2}}$ & 31.26 & 31.16 & 31.08 \\
\hline $\mathbf{T}_{\mathbf{3}}$ & 31.28 & 31.24 & 31.17 \\
\hline $\mathbf{T}_{\mathbf{4}}$ & 31.72 & 31.67 & 31.62 \\
\hline $\mathbf{T}_{\mathbf{5}}$ & 46.28 & 45.78 & 44.40 \\
\hline $\mathbf{T}_{\mathbf{6}}$ & 31.42 & 31.38 & 31.29 \\
\hline $\mathbf{T}_{\mathbf{7}}$ & 31.60 & 31.52 & 31.45 \\
\hline $\mathbf{T}_{\mathbf{8}}$ & 32.17 & 32.09 & 31.98 \\
\hline $\mathbf{T}_{\mathbf{9}}$ & 43.22 & 42.99 & 42.74 \\
\hline $\mathbf{T}_{\mathbf{1 0}}$ & 31.96 & 31.90 & 31.84 \\
\hline $\mathbf{T}_{\mathbf{1 1}}$ & 32.17 & 32.09 & 31.98 \\
\hline $\mathbf{T}_{\mathbf{1 2}}$ & 31.40 & 32.24 & 32.12 \\
\hline $\mathbf{T}_{\mathbf{1 3}}$ & 41.63 & 41.38 & 41.22 \\
\hline $\mathbf{T}_{\mathbf{1 4}}$ & 42.59 & 42.38 & 42.21 \\
\hline $\mathbf{T}_{\mathbf{1 5}}$ & 41.48 & 40.92 & 40.84 \\
\hline $\mathbf{S E d}$ & 0.382 & 0.370 & 0.357 \\
\hline $\mathbf{C D}(\mathbf{0 . 0 5})$ & 0.783 & 0.758 & 0.732 \\
\hline
\end{tabular}

Table.4 Effect of foliar application of micronutrient on leaf copper content (ppm)

\begin{tabular}{|c|c|c|c|}
\hline Treatments & Vegetative stage & Flowering stage & Fruit set stage \\
\hline $\mathbf{T}_{\mathbf{1}}$ & 6.15 & 6.10 & 5.90 \\
\hline $\mathbf{T}_{\mathbf{2}}$ & 7.82 & 7.57 & 6.25 \\
\hline $\mathbf{T}_{\mathbf{3}}$ & 7.65 & 7.45 & 6.19 \\
\hline $\mathbf{T}_{\mathbf{4}}$ & 7.72 & 7.48 & 6.16 \\
\hline $\mathbf{T}_{\mathbf{5}}$ & 7.57 & 7.36 & 6.12 \\
\hline $\mathbf{T}_{\mathbf{6}}$ & 13.88 & 13.32 & 10.83 \\
\hline $\mathbf{T}_{\mathbf{7}}$ & 8.45 & 8.24 & 6.42 \\
\hline $\mathbf{T}_{\mathbf{8}}$ & 8.22 & 8.12 & 6.37 \\
\hline $\mathbf{T}_{\mathbf{9}}$ & 8.43 & 8.21 & 6.31 \\
\hline $\mathbf{T}_{\mathbf{1 0}}$ & 13.24 & 13.16 & 10.67 \\
\hline $\mathbf{T}_{\mathbf{1 1}}$ & 9.12 & 8.89 & 6.52 \\
\hline $\mathbf{T}_{\mathbf{1 2}}$ & 13.34 & 13.23 & 10.73 \\
\hline $\mathbf{T}_{\mathbf{1 3}}$ & 13.19 & 13.01 & 10.57 \\
\hline $\mathbf{T}_{\mathbf{1 4}}$ & 8.68 & 8.35 & 6.49 \\
\hline $\mathbf{T}_{\mathbf{1 5}}$ & 13.26 & 13.11 & 10.61 \\
\hline $\mathbf{S E d}$ & 0.181 & 0.180 & 0.144 \\
\hline $\mathbf{C D}(\mathbf{0 . 0 5})$ & 0.372 & 0.369 & 0.295 \\
\hline
\end{tabular}

The significantly highest $\mathrm{Zn}$ at vegetative, flowering and fruit set stage (35.08, 34.54 and $34.01 \mathrm{ppm}$ ) was found in $\mathrm{T}_{2}$ and the lowest observed in case of $\mathrm{T}_{1}(12.20,11.24$ and $10.23 \mathrm{ppm}$ ) respectively. Increase in leaves $\mathrm{Zn}$ content may be due to its maximum 
absorption from $\mathrm{Zn}$ source and less translocation to the other parts of the plant reported by Sajida and Hafeez (2000) in Kinnow mandarin. Similar trend was observed by Nanaya et al., (1985) in Coorg mandarin and Tariq et al., (2007) in sweet orange, increase in the zinc concentration of treated trees suggested the potential benefit of exogenous application of $\mathrm{Zn}$ in the form of zinc sulfate to these trees.

Leaf $\mathrm{Fe}$ content also varied significantly among the treatments. The highest leaf iron content $(162.1,159.2$ and $158.2 \mathrm{ppm})$ was registered in $\mathrm{T}_{3}$. The lowest leaf iron content of (103.2, 102.3 and $100.8 \mathrm{ppm})$ was recorded in the treatment $\mathrm{T}_{1}$ (Table 2). Increase in leaf iron content due to application of $\mathrm{FeSO}_{4}$ nutrient to leaves reported by Kaur et al., (2015) in Kinnow mandarin. The difference among treatments was significant with respect to manganese, highest leaf manganese content (46.28, 45.78 and $44.40 \mathrm{ppm})$ was found in $\mathrm{T}_{5}$ and the lowest observed in $\mathrm{T}_{1}(30.34,30.25$ and $30.16 \mathrm{ppm}$ ) respectively. This increase in leaf Mn content was due to the better uptake of $\mathrm{Mn}$ ion by sweet orange leaves (Labanwskas et al., 1969). The highest concentration of $\mathrm{Mn}$ was applied alone and combination with $\mathrm{Zn}, \mathrm{Fe}, \mathrm{Cu}$ and boron. Manganese combined with $\mathrm{Zn}, \mathrm{Fe}$ and $\mathrm{Cu}$ in foliar spray mixture increased the Mn content in sprayed leaves but not to the same degree as $\mathrm{Mn}$ alone. Similar results were also reported by El-shazly and Hennawy (1983) and Hafeez and Izhar (2006) who suggested that $\mathrm{Mn}$ combined with $\mathrm{Zn}, \mathrm{Fe}, \mathrm{Cu}$ and $\mathrm{B}$ foliar spray mixture was not as effective in increasing leaf $\mathrm{Mn}$ content as compared to $\mathrm{Mn}$ alone. In case of copper, the elevated leaf copper content (13.88, 13.32 and $10.83 \mathrm{ppm})$ in $\mathrm{T}_{6}$ and reduced content $(6.15,6.10$ and $5.90 \mathrm{ppm}$ ) was noticed in $T_{1}$. Increase in leaves copper content may be due to its readily available of respective nutrients and maximum absorption from nutrient source and less translocation to the other parts of the plant similar results findings were reported by Hassan (1995).

\section{References}

Abd-Allah, A.S. 2006. Effect of spraying some macro and micro nutrients on fruit set, yield and fruit quality of Washington Navel orange trees. $J$. Appl. Sci. Res., 2: 1059-1063.

Ahmad, S.K., Ullah, W., Aman, U.M., Ahmad, R., Saleem, B.A. and Rajwana, I.A. 2012. Exogenous application of boron and zinc influence leaf nutrient status, tree growth and fruit quality of Feutrell's Early (Citrus reticulate Blanco). Pak. J. Agri. Sci., 49(2): 113119.

Alloway, B.J. 2008. Zinc in soils and crop nutrition. Int. Zinc Association Brussel, Belgium.

Anees, M., Tahir, F.M., Shahzad, J. and Mahmood, N. 2011. Effect of foliar application of micronutrient on the quality of mango (Mangifera indica L.) cv. Dusheri fruit. Mycopath., 9(1): 2528.

Anonymous. 2016. http://www.nhb.org.in

Babu, K.D. and Yadav, D.S. 2005. Foliar spray of micronutrients for yield and quality improvement in Khasi mandarin (Citrus reticulata Blanco.). Indian J. Hort., 62: 280-281.

Bergmann, W. 1992. Nutritional Disorders of Plants. Gustav Fischer Verlag Jena Stuttgart, New York.

El-shazly and Hennawy, K. 1983. Effect of foliar application of micronutrients on growth, yield and quality of Washington Novel orange. Ann. Agri. Sci., 45: 213-220.

Hafeez-ur- R and Izhar- ul- H. 2006. Dignostic citeria of micronutrient for sweet orange. Soil Environ., 25(2): 119 127. 
Hassan, A.K. 1995. Effect of foliar spray with some micronutrients on Washington Navel orange tree, tree fruiting and quality. Annals Agr. Sci., 33(4): 1507-1516.

Humphries, E.C. 1956. Mineral composition and ash analysis. In: Modern methods of plant analysis. Vol. I (eds.) K. Peach and M.V. Tracey, Springer-Verlag, Berlin. Pp. 468-502

Jackson, M.C. 1973. Soil Chemical Analysis. Prentice Hall of India Pvt. Ltd., New Delhi. pp.103

Kaur, N., Monga, P.K., Arora, P.K. and Kumar, K. 2015. Effect of micronutrient on leaf composition, fruit quality and yield of Kinnow mandarin. J. Appl. Nat. Sci., 7(2): 639-643.

Labanwskas, C.K., Jones, W.W and Embrleton, T.W. 1963. Effect of foliar application of manganese zinc, and urea on yield and quality of valancencia orange and nutrient concentrations in the leaf, peel and juice. Proc. Amer. Soc. Hort. Sci., 82: 142-153.

Nanaya, K.A., Anjaneylu, K. and Kotur, S.C. 1985. Effect of foliar applied $\mathrm{Zn}, \mathrm{Mn}$, $\mathrm{Cu}$ and $\mathrm{Mg}$ on growth parameters, chlorosis and interrelationships of micronutrients in leaf tissue of Coorg mandarin. Prog. Hort., 17: 309-314.

Obreza, T.A., Zekri, M., Hanlon, E.A., Morgan, K., Schumann, A. and Rouse, R. 2010. Soil and leaf tissue testing for commercial citrus production. University of Florida Extension Service SL 253. Pp: 04.
Sajida, P. and Hafeez-ur- R. 2000. Effect of foliar application of zinc, manganese and boron in combination with urea on the yield of sweet orange. Pak. J. Agri. Res. 16(2): 135-14.

Somasundaram, J., H.R. Meena, R.K. Singh, S.N. Prasad and A.K. Parandiyal. 2011. Diagnosis of micronutrient imbalance in lime crop in semi-arid region of rajastan, India. Communications Soil Sci. Plant Analysis, 42: 858-869.

Srivastava, A.K. and Singh S. 2003. Citrus Nutrition. $1^{\text {st }}$ edition, International Book Distributing Co., Lucknow. Pp: 59.

Swietlik, D. 1999. Zinc nutrition in horticultural crops. In: J. Janick (Ed.). Horticultural Reviews. John Wiley \& Sons, Inc., pp. 109-118.

Swietlik, D. 2002. Zinc nutrition of fruit trees by foliar sprays. Acta Hort., Pp: 594.

Swietlik, D. and Faust, M. 1984. Foliar nutrition of fruit crops. Hortic. Rev., 6: 287-355.

Taiz, L. and Zeiger, E. 1994. Plant Physiology. Second edition. Sinauer Associates, Inc., Publishers. Sunderland, Massachusetts, Pp: 104113.

Tariq, M., Sharif, M., Shah, Z. and Khan, R. 2007. Effect of foliar application of micronutrients on the yield and quality of sweet orange (Citrus sinesis L.). Pak. J. Biol. Sci., 10(11): 1823-1825.

Wiedenhenhoeft, A.C. 2006. Micronutrients. In: plant nutrition. Ed. W.G. Hapkins. Chelsea House Publication, Pp: 14-36.

\section{How to cite this article:}

Nithin Kumar, C.J., J. Rajangam, K. Balakrishnan and Lokesh Bora. 2017. Influence of Foliar Fertilization of Micronutrients on Leaf Micro Nutrient Status of Mandarin Orange (Citrus reticulata Blanco.) in Lower Pulney Hills. Int.J.Curr.Microbiol.App.Sci. 6(5): 516-522. doi: https://doi.org/10.20546/ijcmas.2017.605.060 